\title{
Muscle Atrophy
}

National Cancer Institute

\section{Source}

National Cancer Institute. Muscle Atrophy. NCI Thesaurus. Code C94834.

The loss of muscle tissue due to inactivity or disease. 